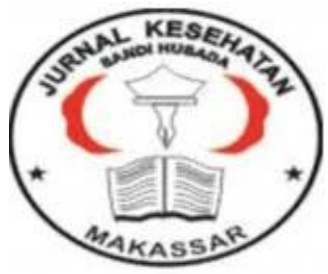

Jurnal Ilmiah Kesehatan Sandi Husada

hhttps://akper-sandikarsa.e-journal.id/JIKSH

Volume 9, Nomor 2, Desember 2020, pp 824-830

p-ISSN: 2354-6093 dan e-ISSN: 2654-4563

DOI: $10.35816 /$ jiskh.v10i2.416

\title{
Analisis Angka Kejadian Penyakit Infeksi Menular Seksual
}

Analysis of the incidence rate of sexually transmitted infections

\author{
Abubakar Betan', Rahmat Pannyiwi² \\ ${ }^{1}$ Keperawatan STIKES Gunungsari \\ ${ }^{2}$ Keperawatan Akademi Keperawatan Yapenas 21 Maros
}

Artikel info

Artikel history:

Received; Agustus 2020

Revised;September 2020

Accepted;September2020

\section{Abstrak}

Latar Belakang; Penyakit menular seksual merupakan penyakit yang menular paling umum dan masalah kesehatan yang saat ini banyak menyita perhatian karena angka kejadian PMS cenderung terus meningkat. Metode; Penelitian kuantitatif menggunakan metode deskriptif analitik dengan rancangan cross sectional studi. Analisis data dengan menggunakan analisis univariat dan bivariate dengan menggunakan uji statistic chi-square. Hasil: uji statistik pengetahuan ( $p=0,009)$, perilaku $(p=0,009)$, dan social ekonomi $(p=0,169)$ dengan kejadian infeksi menular seksual. Kesimpulan; terdapat hubungan pengetahuan dan perilaku dan tidak terdapat hubungan social ekonomi dengan kejadian penyakit menular seksual.

\section{Abstract}

Background; Sexually transmitted diseases are the most common infectious diseases and health problems that are currently getting a lot of attention because the incidence of STDs tends to continue to increase. Method; The quantitative research used descriptive analytical method with a cross sectional study design. Data analysis used univariate and bivariate analysis using the chi-square statistical test. Results: statistical test of knowledge $(p=0.009)$, behavior ( $p$ $=0.009)$, and socioeconomic ( $p=0.169)$ with the incidence of sexually transmitted infections. Conclusion; there is a relationship between knowledge and behavior and there is no socio-economic relationship with the incidence of sexually transmitted diseases.

Keywords:

Behavior,

Knowledge;

Social Economy;

Infection

Contagious

Sexual;
Coresponden author:

Email: abubakar betan@yahoo.com

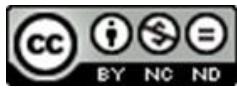

artikel dengan akses terbuka dibawah lisensi CC BY 4.0 


\section{Pendahuluan}

Penyakit menular seksual adalah penyakit yang menular yang paling umum. Hampir separo dari orang Amerika yang ditulari PMS berusia dibawah umur 25 tahun. Banyak di antara remaja yang saat ini tengah menderita PMS tanpa menyadarinya. Bebereapa jenis PMS akan merusak organ reproduksi dalam jika dibiarkan tidak diobati sekalipun tanpa menimbukan gejala seperti nyeri, gatal, atau keluarnya cairan. Walaupun menghadapi bahaya yang ditimbulkan oleh PMS, banyak orang yang merasa segan dan ragu-ragu membicarakan hal ini dengan pasangan seknya (Kemenkes, 2017).

Penyaki Menular Seksual (PMS) merupakan salah satu masalah kesehatan yang saat ini banyak menyita perhatian karena angka kejadian PMS cenderung terus meningkat. Perbedaan signifikan antara metode ceramah dan diskusi terhadap peningkatan pengetahuan siswa tentang Penyakit Menular Seksual (Podding, 2013). Terdapat peningkatan dari kejadian PMS ditengah-tengah masyarakat. Salah satu penyebabnya adalah semakin banyaknya remaja yang melakukan kegiatan seksual, kebanyakan tanpa mengenakan pelindung (seks dengan kondom dianggap 'seks terlindung'). Salah satu alasan lain adalah semakin meluasnya pemakaian pil antihamil. Pil antihamil adalah suatu cara pencegahan kehamilan yang cukup terandalkan-yakni bila diminum secara teratur, hampir dapat dijamin tidak akan terjadi kehamilan (Kuntari, 2010). (Fairfortune, etal, 2020) berpendapat bahwa wanita yang melaporkan pasangan dengan pasangan seks sebelumnya lebih kecil kemungkinannya untuk berhenti menggunakan kondom setelah debut (rasio bahaya $=0,35,0,16-0,77$ ) dibandingkan dengan pasangan yang melaporkan tanpa pasangan sebelumnya. Pada wanita usia kuliah, usia yang lebih tua dan penggunaan kontrasepsi hormonal masing-masing berbanding terbalik dengan penggunaan kondom pada hubungan pertama. Wanita dengan pasangan yang berpengalaman secara seksual lebih cenderung untuk terus menggunakan kondom. Upaya berkelanjutan diperlukan untuk mempromosikan penggunaan kondom di kalangan wanita usia kuliah.

Hasil penelitian (Kusnsan, 2016) menunjukan bahwa terdapat angka 4 (empat) faktor yang sangat erat hubungannya dengan terjadinya penyakit infeksi menular seksual (IMS) yaitu faktor umur responden $<29$ tahun (nilai $\mathrm{P}=0,001<0,05$ ), kurangnya pengetahuan bagi responden (nilai $\mathrm{P}=0,001<0,05$ ) cara hubungan seksual (nilai $\mathrm{P}=0,002<0,05$ ) dan frekuensi hubungan seksual (nilai $\mathrm{P}=0,016$ ). Meningkatkan penyuluhan, khususnya tentang penyakit IMS dan AIDS, meningkatkan sumber daya bidang kesehatan, sehingga penyakit IMS dan AIDS tidak menjadi masalah bagi kesehatan masyarakat. (Suprapto, dkk, 2019) berpendapat terdapat hubungan yang sangat erat antara motivasi dan prestasi belajar, mahasiswa dapat menjaga motivasi menjadi perawat yang sudah tinggi sebagai pendorong untuk meningkatkan prestasi belajar dan lembaga pendidikan agar dapat memotivasi dan memperkenalkan peran perawat di bidang kesehatan dan pendidikan prospek pekerjaan yang cukup menjanjikan untuk masa depan.

AIDS (Acquired Immunodeficiency Syndrome) adalah syndrom yang timbul akibat adanya virus HIV (Human Immunodeficiency Virus) yang menyerang sistem kekebalan tubuh manusia. HIV/AIDS dapat menular melalui darah, sperma, cairan vagina, dan ASI (Air Susu Ibu) (Nursyamsi NL, 2017). IMS dan komplikasi mereka di peringkat lima teratas kategori penyakit yang dewasa mencari perawatan kesehatan. Infeksi dengan IMS dapat menyebabkan gejala akut, infeksi kronis dan konsekuensi tertunda serius seperti infertilitas, kehamilan ektopik, kanker leher rahim dan kematian mendadak bayi dan orang dewasa. Tujuan penelitian mengetahui faktor yang berhubungan dengan kejadian Penyakit infeksi menular seksual di wilayah kerja puskesmas Andalas Kota Makassar. 


\section{Metode}

Penelitian kuantitatif menggunakan metode deskriptif analitik dengan rancangan cross sectional studi untuk mencari hubungan variabel dependen dan variabel independen yang diamati pada periode waktu yang sama untuk melihat faktor yang berhubungan dengan kejadian infeksi menular. Populasi dalam penelitian ini sebanyak 34 responden. Sampel dalam penelitian ini adalah semua penderita yang menderita penyakit infeksi menular seksual yang ada diwilayah kerja puskesmas Andalas Kota Makassar pada saat penelitian berlangsung dengan kriteria inklusi bersedia menjadi responden, pasien terkena infeksi. Analisis data dengan menggunakan analisis univariat dan bivariate dengan menggunakan uji statistic chi-square. Pengujian hipotesis dilakukan dengan uji Chi-Square dan alternatifnya menggunakan program SPSS dengan tingkat kemaknaan $\alpha=0,05$.

Hasil Dan Pembahasan

Tabel.1 Demografi Responden dan Analisis Univariat Subyek Penelitian $\begin{array}{lll}\text { Jenis Kelamin } & \text { Frekuensi(n) } & \text { Persentase (\%) }\end{array}$

\begin{tabular}{|c|c|c|}
\hline Laki-laki & 7 & 20,6 \\
\hline Perempuan & 27 & 79,4 \\
\hline Total & 34 & 100 \\
\hline \multicolumn{3}{|l|}{ Umur } \\
\hline $20-30$ tahun & 17 & 50 \\
\hline $31-40$ tahun & 13 & 38,2 \\
\hline $41-50$ tahun & 3 & 8,8 \\
\hline$>50$ tahun & 1 & 3 \\
\hline Total & 34 & 100 \\
\hline \multicolumn{3}{|l|}{ Pendidikan } \\
\hline SD & 8 & 23,5 \\
\hline SMP/SMA & 22 & 64,7 \\
\hline Sarjana & 4 & 11,8 \\
\hline Total & 34 & 100 \\
\hline \multicolumn{3}{|l|}{ Pengetahuan } \\
\hline Baik & 26 & 76,5 \\
\hline Kurang & 8 & 23,5 \\
\hline Total & 34 & 100 \\
\hline \multicolumn{3}{|l|}{ Prilaku } \\
\hline Baik & 8 & 23,5 \\
\hline Kurang & 26 & 76,5 \\
\hline Total & 34 & 100 \\
\hline \multicolumn{3}{|c|}{ Sosial ekonomi } \\
\hline Baik & 18 & 52,9 \\
\hline Kurang & 16 & 47,1 \\
\hline Total & 34 & 100 \\
\hline
\end{tabular}

Sumber: data primer 2020 
Tabel .2 Analisis Hubungan Perilaku, Pengetahuan dan Sosial Ekonomi dengan Penyakit Infeksi Menular Seksual

\begin{tabular}{|c|c|c|c|c|c|c|}
\hline \multirow{3}{*}{ Prilaku } & \multicolumn{4}{|c|}{ Infeksi Menular Seksual } & \multirow{2}{*}{\multicolumn{2}{|c|}{ Jumlah }} \\
\hline & \multicolumn{2}{|c|}{ Baik } & \multicolumn{2}{|c|}{ Kurang } & & \\
\hline & $\mathrm{N}$ & $\%$ & $\mathrm{~N}$ & $\%$ & $\mathrm{~N}$ & $\%$ \\
\hline Baik & 26 & 76,5 & 0 & 0 & 26 & 76,6 \\
\hline Kurang & 6 & 17,6 & 2 & 5,9 & 8 & 23,5 \\
\hline Total & 32 & 94,1 & 2 & 5,9 & 34 & 100 \\
\hline \multicolumn{7}{|c|}{ Pengetahuan } \\
\hline Baik & 26 & 76,5 & 0 & 0 & 26 & 76,6 \\
\hline Kurang & 6 & 17,6 & 2 & 5,9 & 8 & 23,5 \\
\hline Total & 32 & 94,1 & 2 & 5,9 & 34 & 100 \\
\hline \multicolumn{7}{|c|}{ Sosial ekonomi } \\
\hline Baik & 16 & 47,1 & 2 & 5,9 & 18 & 52,9 \\
\hline Kurang & 16 & 47,1 & 0 & 0 & 16 & 47,1 \\
\hline Total & 32 & 94,2 & 2 & 5,9 & 34 & 100 \\
\hline
\end{tabular}

Sumber: data primer 2020

Berdasarkan tabel 1 analisis univariat dari 34 responden, 26 (76, 5\%) diantaranya memiliki pengetahuan yang baik tentang infeksi menular seksual dan $8(23,5 \%)$ responden memiliki pengetahuan yang kurang dan dari 34 responden, 26 (76,5\%) diantaranya memiliki prilaku yang kurang dan 8 (23,5\%) responden memiliki prilaku yang baik tentang infeksi menular seksual.

Dari tabel 2 hasil penelitian yang dilakukan pada 34 responden, dimana ternyata data responden dengan prilaku yang baik tentang kejadian infeksi menular seksual sebanyak 26 perawat $(76,5 \%)$ dan responden dengan prilaku kurang tentang kejadian infeksi menular seksual 6 responden (17,6\%). Dari hasil uji statistic diperoleh nilai $p=0,009$ dengan tingkat kemaknaan $\alpha=0,05$. Hal ini menunjukkan bahwa nilai $p<\alpha$, berarti ada hubungan tingkat prilaku dengan kejadian infeksi menular seksual di puskesmas Andalas kota Makassar. Hasil penelitian yang dilakukan pada 34 responden, dimana ternyata data responden tentang sosial ekonomi yang baik dengan kejadian infeksi menular seksual sebanyak 18 responden $(52,9 \%)$ dan responden yang mengatakan sosial ekonomi yang kurang dengan kejadian infeksi menular seksual sebanyak 16 responden $(47,1 \%)$. Dari hasil uji statistik diperoleh nilai $p=0,169$ dengan tingkat kemaknaan $\alpha=0,05$. Hal ini menunjukkan bahwa nilai $\mathrm{p}<\alpha$, berarti tidak ada hubungan sosial ekonomi dengan kejadian infeksi menular seksual di puskesmas Andalas Kota Makassar.

Pengetahuan merupakan hasil dari tahu dan ini terjadi setelah orang melakukan pengindraan terhadap obyek tertentu. Pengindraan terjadi melalui panca indra manusia, yakni indra penglihatan, pendengaran, penciuman, rasa dan raba. Sebagian besar pengetahuan manusia diperoleh melalui mata dan telinga. Pengetahuan atau kognitif merupakan dominan yang sangat penting untuk terbentuknya tindakan seseorang (Notoatmodjo, 2003). Dari hasil penelitian yang dilakukan pada 34 responden, dimana ternyata data responden dengan tingkat pengetahuan yang baik tentang infeksi menular seksual sebanyak 26 perawat $(76,5 \%)$ dan responden dengan tingkat pengetahuan kurang tentang tentang infeksi menular seksual sekitar 6 responden $(17,6 \%)$. Uji statistic diperoleh nilai $p=0,009$ dengan tingkat kemaknaan $\alpha=0,05$. hal ini menunjukkan bahwa nilai $\mathrm{p}<\alpha$, berarti ada hubungan tingkat pengetahuan dengan kejadian infeksi menular seksual di puskesmas Kota Makassar. 
Hasil penelitian (Pangaribuan, dkk, 2017) menunjukkan sebanyak 44 responden (51,76\%) memiliki pengetahuan yang cukup, 32 responden $(37,65 \%)$ memiliki pengetahuan yang baik dan 9 responden $(10,59 \%)$ masih kurang. Hasil prosentasi tersebut dapat ditunjukkan dari kontent sub variabel pengertian, penyebab, jenis dan gejala, dampak dan cara pencegahan IMS yang berada pada kategori baik dan cukup sedangkan cara kontent tentang penularan IMS berada pada kategori kurang, kondisi ini yang di asumsikan bahwa peningkatan IMS masih terus meningkat. Hasil penelitian (Fatimah, 2013) menunjukkan bahwa 58\% responden memiliki perilaku pencegahan penularan IMS yang baik. Ada hubungan yang signifikan antara pengetahuan terhadap tingkat perilaku pencegahan penularan IMS $(\mathrm{p}=0,000)$ dan ada hubungan yang signifikan antara sikap terhadap tingkat perilaku pencegahan penularan IMS $(\mathrm{p}=0,000)$.

Perilaku adalah apa yang dikerjakan oleh organisme, baik yang dapat diamati secara langsung maupun tidak langsung. Perilaku manusia pada hakikatnya adalah suatu aktifitas dari pada manusia itu sendiri, oleh karena itu perilaku manusia mempunyai bentangan yang sangat luas. Perilaku manusia dipengaruhi oleh faktor genetik dan sosial ekonomi. Herediter merupakan konsep dasar atau untuk perkembangan perilaku mahluk hidup itu. Sedangkan sosial ekonomi merupakan kondisi atau lahan untuk perkembangan perilaku tersebut (Notoatmodjo, 2009). Hasil penelitian (Sari, 2009) menunjukkan dari 85 responden tingkat pengetahuan responden tentang PMS sebagian besar mempunyai pengetahuan baik $(58,8 \%)$, sebagian berpengetahuan cukup $(38,8 \%)$, dan yang berpengetahuan kurang hanya $(2,4 \%)$ dan data perilaku seksual menunjukkan sebagian besar siswa siswi mempunyai perilaku positif $(75,3 \%)$ dan $(24,7 \%)$ siswa mempunyai perilaku negatif. Hubungan antara kedua variabel adalah signifikan yang menunjukkan adanya hubungan positif antara tingkat pengetahuan Penyakit Menular Seksual (PMS) dengan perilaku seksual pranikah.

Pengetahuan, sikap, usia, akses alat seksual, perilaku seksual pasangan, dan perilaku seksual teman komunitas. Faktor yang berhubungan dengan perilaku seksual berisiko IMS adalah akses alat seksual, perilaku seksual pasangan, dan perilaku seksual teman komunitas (Noviyani, 2017). Perilaku mempunyai instrumental, artinya dapat berfungsi dan memberi pelayanan terhadap kebutuhan. Seseorang dapat bertindak (berperilaku) positif terhadap obyek demi pemenuhan kebutuhan, sebaliknya bila obyek tidak memenuhi kebutuhan maka ia akan berperilaku negatif. Sosial ekonomi dapat diartikan sebagai segala benda, keadaan dan pengaruh yang terdapat dalam ruang yang kita tempati dan mempengaruhi segala hal-hal yang hidup, termasuk manusia Kesejahteraan manusia sangat dipengaruhi oleh sosial ekonominya, sosial ekonomi yang kurang baik, atau sama sekali tidak menguntungkan akan memberikan dampak negatif, sedangkan sosial ekonomi yang baik akan meningkatkan kesehatan. Oleh sebab itu diperlukan upaya antisipatif agar hal-hal yang bersifat negatif dapat dikendalikan, sedangkan hal-hal yang positif dapat (Notoatmodjo, 2009).

(Suprapto, 2019) berpendapat bahwa ada hubungan antara kepuasan dengan prestasi kerja perawat. Ada hubungan yang signifikan antara kepuasan kerja dengan prestasi kerja di ruang perawatan rumah sakit. Dalam memberikan pelayanan kesehatan yang baik dan berkualitas baik dari segi pelayanan, perawatan maupun fasilitas yang baik bagi pasien. Kepuasan kerja terbukti memberikan hubungan yang relatif baik terhadap peningkatan prestasi kerja, juga tidak menutup kemungkinan bagi perusahaan untuk mempertimbangkan faktor lain yang dapat memberikan kemudahan di bidang pelayanan kesehatan. Didukung dengan hasil penelitian (Astuti, 2018) bahwa tidak ada hubungan antara pengetahuan dengan IMS (Infeksi menular seksual) dengan p-value $=>0.05$, ada hubungan antara pendidikan dengan IMS (Infeksi menular seksual) dengan $p$-value $=<$ 
0.05,dan tidak ada hubungan antara sosial ekonomi dengan IMS (Infeksi menular seksual) dengan $\mathrm{p}$-value $=>0.05$. tidak ada hubungan antara pengetahuan dengan kejadian IMS (Infeksi menular seksual), ada hubungan Pendidikan dengan kejadian IMS, tidak ada hubungan Sosial ekonomi dengan kejadian IMS (Infeksi Menular Seksual). Hasil penelitian (Putri, 2015) menunjukkan tidak ada hubungan antara tingkat ekonomi dengan kejadian IMS. Pengaruh yang paling besar terhadap kejadian IMS adalah perilaku yang kurang dengan dan kurangnya partisipasi aktif dari masyarakat dalam upaya mencegah terjadinya penyebaran penyakit IMS, seperti memperbaiki perilaku dengan bersikap setia, tidak bertukar pasangan.

\section{Simpulan Dan Saran}

Ada hubungan antara tingkat pengetahuan, perilaku dengan infeksi menular seksual dan tidak ada hubungan sosial ekonomi terhadap infeksi menular seksual di puskesmas andalas Kota Makassar. Perlu adanya peningkatan sumber daya manusia utamanya perawat melalui pendidikan atau pelatihan untuk meningkatkan keterampilan khususnya dalam pencegahan infeksi menular seksual.

\section{Daftar Rujukan}

Astuti, T. (2018). Faktor-Faktor Yang Berhubungan Dengan Kejadian Ims (Infeksi Menular Seksual) Pada Psk (Pekerja Seks Komersial) Di Puskesmas Prambanan Sleman Di Yogyakarta. Jurnal Ilmiah Kesehatan Ar-Rum Salatiga, 2(2), 1-8.

Fairfortune, T. S., Stern, J. E., Richardson, B. A., Koutsky, L. A., \& Winer, R. L. (2020). Sexual Behavior Patterns and Condom Use in Newly Sexually Active Female University Students. Archives of Sexual Behavior, 49(3), 1053-1065.

Fatimah, S. (2013). Hubungan Antara Pengetahuan Dan Sikap Pasien Infeksi Menular Seksual (Ims) Dengan Perilaku Pencegahan Penularan IMS di Wilayah Kerja Puskesmas Kom Yos Sudarso Pontianak. Tanjungpura University.

Kemenkes, R. I. (2017). Laporan Perkembangan HIV-AIDS dan Penyakit Infeksi Menular Seksual (PMS) Triwulan I Tahun 2017. Diakses Dari: Http://Www. Siha. Depkes. Go. Id Pada Tanggal, 1.

Kuntari, T. (2010). Penyakit Menular Seksual, Hiv\& Aids.

Kusnsan, A. (2016). Analisis Hubungan Determinan Kejadian Penyakit Infeksi Menular Seksual (IMS) pada Wanita Penjaja Seksual (WPS). Jurnal Kesehatan, 4(2).

Notoatmodjo, S. (2003). Pendidikan dan perilaku kesehatan. Jakarta: Rineka Cipta, 16, 1549.

Notoatmodjo, S. (2009). Pendidikan dan Perilaku Manusia. Jakarta: PT Rieneka Cipta.

Noviyani, D. (2017). Perilaku Seksual Berisiko Infeksi Menular Seksual (Ims) Pada Kelompok Lesbi Di Kota Semarang. JHE (Journal of Health Education), 2(2), 122129.

Nursyamsi NL. (2017). Tingkat Pengetahuan Mahasiswa Tentang Hiv/Aids di Akademi Kebidanan Sandi Karsa Makassar. Jurnal Ilmiah Kesehatan Sandi Husada, 5(2), 112.

Pangaribuan, S. M., \& Mardiah, W. (2017). Gambaran Tingkat Pengetahuan Wanita Pekerja Seks Komersial Tentang Infeksi Menular Seksual. Jurnal Pendidikan Keperawatan Indonesia, 3(2), 175-181.

Podding, I. T. (2013). Studi Perbandingan Efektifitas metode Ceramah Dan Diskusi Terhadap Peningkatan Pengetahuan Siswa Tentang Penyakit Menular Seksual Di SMAN 1 SabbangParu Kabupaten Wajo. Jurnal Ilmiah Kesehatan Diagnosis, 3(2), 20-24.

Putri, A. (2015). Pengaruh Pengetahuan, Sikap, Perilaku Pencegahan Dan Tingkat Ekonomi 
Terhadap Kejadian Infeksi Menular Seksual Pada Pasien Puskesmas Kecamatan Ciracas Jakarta Timur Februari-Maret 2015. Universitas Pembangunan Nasional Veteran Jakarta.

Sari, T. P. (2009). Hubungan antara tingkat pengetahuan penyakit menular seksual dengan perilaku seksual pranikah pada siswa siswi SMAN 3 Surakarta.

Suprapto. (2019). Relationship between satisfaction with nurse work performance in health services in hospitals. Indian Journal of Public Health Research and Development, 10(10), 785-788. https://doi.org/10.5958/0976-5506.2019.02912.7

Suprapto, S., Malik, A. A., \& Yuriatson, Y. (2019). Relationship of Motivation to Be a Nurse with Learning Achievement. Jurnal Ilmiah Kesehatan Sandi Husada, 10(2), 39-43. 